\title{
The association of Pro12Ala polymorphism of peroxisome proliferator-activated receptor- $\gamma$ gene with serum osteoprotegerin levels in healthy Korean women
}

\author{
Eun-Jung Rhee ${ }^{1 *}$, Ki-Won Oh ${ }^{1,5_{*}}$, Eun-Joo Yun ${ }^{2}$, \\ Chan-Hee Jung ${ }^{1}$, Cheol-Young Park', \\ Won-Young Lee ${ }^{1}$, Eun-Sook $\mathrm{Oh}^{3}$, Ki-Hyun Baek ${ }^{4}$, \\ Moo-II Kang ${ }^{4}$, Sung-Woo Park ${ }^{1}$ and Sun-Woo Kim ${ }^{1}$ \\ ${ }^{1}$ Department of Endocrinology and Metabolism \\ Sungkyunkwan University School of Medicine \\ Seoul 135-710, Korea \\ 2Department of Radiology, Hallym University \\ Seoul 134-701, Korea \\ ${ }^{3}$ Department of Endocrinology and Metabolism \\ Miz Medi Hospital, Seoul 157-280, Korea \\ ${ }^{4}$ Department of Endocrinology and Metabolism \\ The Catholic University of Korea, College of Medicine \\ Seoul 137-701, Korea \\ ${ }^{5}$ Corresponding author: Tel, 82-2-2001-2482; \\ Fax, 82-2-2001-1588; E-mail, okwendo @yahoo.co.kr \\ *These authors contributed equally to this work.
}

Accepted 17 September 2007

Abbreviations: ADOPT, a diabetes outcome progression trial; ALP, alkaline phosphatase; ANCOVA, analysis of covariance; BMD, bone mineral density; DPD, deoxypyridinoline; DXA, dual energy X-ray absorptiometer; FSH, follicle stimulating hormone; Health $A B C$, Health, aging and body composition; OPG, osteoprotegerin; PPAR $-\gamma$, peroxisome proliferator-activated receptor- $\gamma$

\begin{abstract}
Recent evidences suggest that the activation of peroxisome proliferator-activated receptor (PPAR) $-\gamma$, which is an important transcriptional factor in adipocyte differentiation, also plays an important role in the bone microenvironment. The objective of the study was to clarify whether Pro12Ala polymorphism was related to the serum OPG levels and bone mineral metabolism in healthy Korean women. In 239 Korean women (mean age 51 years), who participated in medical check-up program in a health promotion center, anthropometric measurements, lumbar spine and femoral neck bone mineral density (BMD), bone turnover markers, such as serum total alkaline phosphatase (ALP) levels, urine deoxypyridinoline levels, and 24-h urine calcium excretion were measured. Serum levels of OPG were
\end{abstract}

measured with ELISA method. DNAs were extracted from the samples and the genotyping of the Pro12Ala polymorphism (rs1801282) in the PPAR- $\gamma$ gene was performed via an allelic discrimination assay using a TaqMan probe. In addition, we examined the haplotype analysis between two polymorphisms of PPAR- $\gamma$ gene, Pro12Ala in exon B and C161T in exon 6 (rs3856806). Allelic frequencies were 0.950 for Pro allele and 0.050 for Ala allele, which was in compliance with HardyWeinberg equilibrium, and there was no Ala12Ala genotype among the genotyped subjects. Mean serum OPG level was significantly lower $(P=0.035)$, and serum total ALP was significantly higher $(P=0.014)$ in the Pro12Ala genotype group compared with the Pro12Pro genotype group, which were consistently significant even after adjustment for weight, height, and serum follicle stimulating hormone (FSH). In multiple regression analysis with serum OPG as the dependent variable and age, weight, ALP, femoral neck BMD and Pro12Ala genotype included in the model, only Pro12Ala genotype was significant determinant of serum OPG level $(\beta=-0.136, P=0.035)$. The haplotype analysis with C161T polymorphism revealed that subjects with Ala and $T$ alleles showed significantly lower serum OPG levels compared with those with Pro12Pro/CC genotype, which were consistently significant even after adjustment for age, weight, height and FSH $(P=0.010)$. This result suggests statistically significant association of Pro12Ala polymorphisms with serum OPG levels in Korean females.

Keywords: alkaline phosphatase; bone and bones; PPAR- $\gamma$; polymorphism, genetic; osteoprotegerin

\section{Introduction}

Peroxisome proliferator-activated receptor (PPAR)$\gamma$ belongs to the nuclear hormone receptor family, which is predominantly expressed in the adipose tissue, and is a major determinant for the terminal differentiation of adipocyte (Kersten et al., 2000). Recent studies report its possible involvement in the pathogenesis in insulin resistance, inflammation, atherosclerosis, and malignancy (Desvergne and Wahli, 1999). Based on the fact that osteo- 
blasts and adipocytes share a common mesenchymal precursor, recent studies have demonstrated that the activation of PPAR- $\gamma$ stimulated adipocyte differentiation and simultaneously blocked their ability to differentiate into osteoblasts or promoted their apoptosis (Nuttall et al., 1998; Lecka-Czernik et al., 1999, 2002; Rosen and Spiegelman, 2001; Sorocéanu et al., 2004). In addition, PPAR- $\gamma$ activation seems to have regulatory effects on bone metabolism through regulating their differentiation or activation into osteoclasts (Okazaki et al., 1999; Mbalaviele et al., 2000; Chan et al., 2007). However, the evidences on whether PPAR- $\gamma$ activation might affect bone metabolism through activation or inhibition of either cell lineages are not enough to draw a conclusion.

Not so apart from the results of in vitro studies, in recently reported large clinical studies on the comparison among the glycemic durability of three classes of hypoglycemic agents (A Diabetes Outcome Progression Trial, ADOPT), significantly more women who received rosiglitazone, one of the PPAR- $\gamma$ agonists, experienced fractures of the upper arm, hand, or foot than did women who received either of the other drugs (Kahn et al., 2006). Another recent observational study by Schwartz et al. (2006) from the Health, Aging and Body Composition (Health $A B C$ ) study, suggests that the treatment of diabetic women with thiazolidinedione is associated with a significant $50 \%$ increase in the annual rate of whole-body bone loss. Although the results does not have enough power to draw a conclusion, since none of these trials are randomized or blinded clinical trials designed with the end point to see the effect of thiazolidinediones on fracture rate or bone mineral density changes, more theretical and academic approaches are needed on this issue.

The most frequently occurring PPAR- $\gamma$ polymorphism is the substitution of proline to alanine (Pro12Ala) in exon B of the PPAR- $\gamma 2$ gene (rs1801282), and numerous polymorphism studies have been performed on its association with type 2 diabetes mellitus, insulin resistance and obesity, although the significance of such associations remains still a debate (Fajas et al., 1997; Mancini et al., 1999; Ringel et al., 1999; Altshuler et al., 2000; Clement et al., 2000; Hara et al., 2000; Meirhaeghe et al., 2000). The next most frequently occurring PPAR- $\gamma$ polymorphism is $\mathrm{C} \rightarrow \mathrm{T}$ substitution in exon 6 (rs3856806), which was identified by Meirhaegue et al. (2000), and it was shown to have significant association with bone mineral density (BMD) in postmenopausal Japanese women (Ogawa et al., 1999). Furthermore, our previous polymorphism study performed in Korean women showed a significant association of this polymorphism with serum osteoprotegerin (OPG) level, a key inhibitor of osteoclastogenesis (Rhee et al., 2005). However, no study has been performed on the relationship between Pro12Ala polymorphism and bone metabolism or serum OPG levels as yet.

We have previously published a paper on the association of two PPAR- $\gamma$ polymorphisms with metabolic syndrome in Korean subjects (Rhee et al., 2006). Here we investigated the influence of PPAR- $\gamma$ gene polymorphism on serum OPG and bone mineral metabolism through analyzing the differences in serum OPG levels, BMD values and bone turnover markers according to the different genotypes of Pro12Ala polymorphism of exon B of PPAR- $\gamma$ gene, and through the haplotype analyses with C161T polymorphism in exon 6 of PPAR- $\gamma$ in Korean adult women.

\section{Materials and Methods}

\section{Subjects}

Among the female participants who underwent health check-ups including BMD measurements in MizMedi health promotion center, Seoul, Korea, from January to December, 2002, we selected 239 women for our study, excluding those with diseases affecting bone metabolism including pituitary disease, thyroid diseases, parathyroid diseases, chronic renal disease, chronic liver disease, and we also excluded those subjects who were taking medications that might affect bone metabolism such as adrenocortical hormone, thyroid hormone, estrogen, bisphosphonate, calcitonin, calcitriol and etc. The subjects included 125 postmenopausal women and 114 premenopausal women. Menopause was defined as the absence of menstruation for 12 months after the last menstruation and a follicle stimulating hormone (FSH) level higher than $40 \mathrm{mIU} / \mathrm{ml}$. Height $(\mathrm{cm})$ and weight $(\mathrm{kg})$ were measured in all subjects. All the subjects agreed to participate in the study, and the study protocol was approved by a relevant ethics committee.

\section{Measurements of serum OPG levels}

The serum OPG levels of the study subjects were measured by ELISA (Oscotec, Korea). After more than $8 \mathrm{~h}$ of overnight fasting, blood samples were obtained in the morning, serum was separated, stored at $-70^{\circ} \mathrm{C}$, and measured simultaneuously later. All the measurements were repeated twice, and the average values were obtained. In regard to the accuracy of the measurement of serum OPG levels, the intra-assay coefficient of variance was 
$6.9-9.0 \%$, and the inter-assay coefficient of variance was $6.0-9.0 \%$.

\section{Measurements of BMD and bone turnover markers}

BMD was measured from the lumbar spine and the femoral neck of the study subjects using a dual energy X-ray absorptiometer (DXA, XR-series, Norland, Instruments, Fort Atkinson, WI). Concerning the accuracy of the measurement of BMD, coefficient of variation was $1.0 \%$ for lumbar spine vertebra, and $1.2 \%$ for femoral neck. T-scores for the lumbar spine and femoral neck were calculated on the basis of the standardized records of healthy Korean women.

As bone turnover markers, serum total alkaline phosphatase (total ALP, multiple point rate colorimetric, Vitros 750 XRC, Ortho-Clinical Diagnostics, Rochester, NY) levels were measured as the bone formation marker, and urine deoxypyridinoline (chemiluminescence immunoassay, ACS- 180, CIBA-corning, Medfield, MA) levels were measured as the bone resorption marker, and serum calcium levels and 24-h urine calcium excretion were measured (colorimetric, Vitros 750 XRC, Ortho-Clinical Diagnostics, Rochester, NY). Regarding the accuracy of urine deoxypyridinoline, intra-assay coefficient of variance was $1.1-3.7 \%$, and inter-assay coefficient variance was $4.0-10.0 \%$. $\mathrm{FSH}$ levels were measured with chemiluminescent sandwich immunoassay (ADVIA Centaur Assay, Bayer Diagnostics, Tarrytown, NY). Regarding the accuracy of serum $\mathrm{FSH}$, the intra-assay coefficient of variance was $2.0-2.9 \%$, and the inter-assay coefficient of variance was $0.3-2.7 \%$.

\section{Genotypings}

The buffy coat was separated from the blood samples of the study subjects and stored at $-70^{\circ} \mathrm{C}$, and genomic DNA was extracted by using a DNA purification kit (Takara Bio Inc., Japan).

The analysis of the Pro12Ala polymorphisms of PPAR- $\gamma$ gene was performed by the allelic discrimination assay using TaqMan probe and the analysis of the C161T polymorphisms of PPAR- $\gamma$ gene was performed by RFLP as described before (Rhee et al., 2005, 2006).

\section{Statistical analysis}

All the results were presented as the mean \pm standard deviation, and statistical significance was defined as $P$ values less than 0.05 . The appropriateness of the allele frequencies of the Pro12Ala polymorphism in the PPAR- $\gamma$ gene was analyzed by Hardy-Weinberg equilibrium using chi-square test. The program HaploView V3.2 was used to identify linkage disequilibrium (LD) blocks (Barrett et al., 2005). One-way ANOVA and independentsamples $t$-test were used to compare the differences in each group. The analysis of covariance (ANCOVA) test was used to adjust the effects of weight, height, and serum $\mathrm{FSH}$ to the variable that showed significant differences among different groups. Multiple comparisons were performed with post-hoc analyses by LSD method. Multiple regression analyses were performed with Backward method with serum OPG level as the dependent variable. The Shapiro-Wilk test was used for normality analysis, and the nonparametric MannWhitney $U$ test and Kruskal-Wallis $H$ test were used to compare the variables not satisfying the normality test.

\section{Results}

The mean age of the study population was $51.4 \pm$ $6.7 \mathrm{yrs}$, the mean weight was $58.7 \pm 7.9 \mathrm{~kg}$, and the mean height was $156.3 \pm 5.1 \mathrm{~cm}$ (Table 1).

Of the 239 subjects, the frequencies of the each genotype for Pro12Ala polymorphism in PPAR- $\gamma$ gene were 90\% $(n=215)$ for Pro12Pro, 10\% $(n=$ 24) for Pro12Ala, and there was no Ala12Ala genotype among the genotyped subjects. The allele frequency for the proline was 0.950 and 0.050 for the alanine, and they were in compliance with the Hardy-Weinberg equilibrium $(P=0.716)$. The genotype distribution and the allelic frequencies of the C161T polymorphism of PPAR- $\gamma$ gene in the in-

Table 1. General characteristics of the subjects.

\begin{tabular}{lc}
\hline \multicolumn{1}{c}{ Variables $(n=239)$} & Means \pm SDs \\
\hline Age $($ years $)$ & $51.4 \pm 6.7$ \\
Weight $(\mathrm{kg})$ & $58.7 \pm 7.9$ \\
Height $(\mathrm{cm})$ & $156.3 \pm 5.1$ \\
Serum osteoprotegerin $(\mathrm{pg} / \mathrm{ml})$ & $1311.4 \pm 393.7$ \\
Serum creatinine $(\mathrm{mg} / \mathrm{dl})$ & $0.70 \pm 0.09$ \\
Serum calcium $(\mathrm{mg} / \mathrm{dl})$ & $9.01 \pm 0.35$ \\
Serum total alkaline phosphatase $(\mathrm{mg} / \mathrm{dl})$ & $59.7 \pm 17.7$ \\
Urine deoxypyridinoline $(\mathrm{nMol} / \mathrm{mMol} \mathrm{Cr})$ & $7.09 \pm 2.06$ \\
24-h urine Ca/Cr & $0.22 \pm 0.12$ \\
Lumbar spine BMD $\left(\mathrm{g} / \mathrm{cm}^{2}\right)$ & $0.956 \pm 0.170$ \\
Femoral neck BMD $\left(\mathrm{g} / \mathrm{cm}^{2}\right)$ & $0.799 \pm 0.121$ \\
TSH (mlU/l) & $1.94 \pm 1.25$ \\
FSH (mlU/ml) & $40.9 \pm 31.6$ \\
\hline
\end{tabular}

Abbreviations: $\mathrm{Ca} / \mathrm{Cr}$, calcium to creatinine ratio; $\mathrm{BMD}$, bone mineral density; TSH, thyroid stimulating hormone; $\mathrm{FSH}$, follicle stimulating hormone. 
Table 2. Comparison of the variables between different genotypes of Pro12Ala polymorphism in PPAR- $\gamma$ gene.

\begin{tabular}{|c|c|c|c|}
\hline Genotypes & Pro12Pro $(n=215)$ & Pro12Ala $(n=24)$ & $P$ values \\
\hline Age (year) & $51.3 \pm 6.7$ & $52.2 \pm 7.4$ & 0.531 \\
\hline Weight (kg) & $58.3 \pm 7.8$ & $62.4 \pm 8.3$ & 0.015 \\
\hline Height $(\mathrm{cm})$ & $156.1 \pm 5.1$ & $158.3 \pm 4.6$ & 0.042 \\
\hline Serum osteoprotegerin (pg/ml) & $1329.3 \pm 391.1$ & $1150.9 \pm 388.4$ & $0.035^{\star}$ \\
\hline Serum calcium (mg/dl) & $9.00 \pm 0.35$ & $9.09 \pm 0.33$ & 0.257 \\
\hline Serum total ALP $(U / I)$ & $58.7 \pm 17.3$ & $68.1 \pm 19.2$ & $0.014^{\dagger}$ \\
\hline Urine DPD (nMol/mMol Cr) & $7.04 \pm 1.96$ & $7.56 \pm 2.79$ & 0.238 \\
\hline 24-h urine $\mathrm{Ca} / \mathrm{Cr}$ & $0.226 \pm 0.129$ & $0.203 \pm 0.070$ & 0.429 \\
\hline Lumbar spine BMD $\left(\mathrm{g} / \mathrm{cm}^{2}\right)$ & $0.956 \pm 0.173$ & $0.954 \pm 0.134$ & 0.953 \\
\hline Lumbar spine BMD/Height $\left(\mathrm{g} / \mathrm{cm}^{2} \cdot \mathrm{m}\right)$ & $0.612 \pm 0.107$ & $0.603 \pm 0.086$ & 0.684 \\
\hline Femoral neck BMD $\left(\mathrm{g} / \mathrm{cm}^{2}\right)$ & $0.800 \pm 0.121$ & $0.797 \pm 0.123$ & 0.916 \\
\hline Femoral neck BMD/height $\left(\mathrm{g} / \mathrm{cm}^{2} \cdot \mathrm{m}\right)$ & $0.512 \pm 0.074$ & $0.504 \pm 0.076$ & 0.594 \\
\hline $\mathrm{FSH}(\mathrm{mlU} / \mathrm{ml})$ & $39.8 \pm 31.8$ & $50.5 \pm 28.7$ & 0.117 \\
\hline
\end{tabular}

Comparisons were performed using independent-samples $t$-test.

Abbreviations: ALP, alkaline phosphatase; DPD, deoxypyridinoline; $\mathrm{Ca} / \mathrm{Cr}$, calcium to creatinine ratio; BMD, bone mineral density; FSH, follicle stimulating hormone. *Adjustment were performed using ANCOVA; weight $(P=0.039)$, height $(P=0.030)$, FSH $(P=0.019)$, weight and height $(P=0.035)$, and weight, height, and FSH $(P=0.015) .{ }^{\dagger}$ Adjustment were performed using ANCOVA; weight $(P=0.020)$, height $(P=0.009)$, FSH $(P=0.044)$, weight and height $(P=0.014)$, and weight, height, and FSH $(P=0.068)$.

dentical study population were reported previously (Rhee et al., 2005). In the linkage analysis, the linkage disequilibrium detected between the two polymorphisms of PPAR- $\gamma$ gene was not so significant $\left(D^{\prime}=0.57, r^{2}=0.07\right)$.

In Pro12Ala polymorphism of PPAR- $\gamma$ gene, subjects with the Pro12Ala genotype showed higher weight and height than subjects with the Pro12Pro genotype (Table 2). Mean serum OPG level was significantly lower in the Pro12Ala genotype group compared with the Pro12Pro genotype group $(1150.9 \pm 388.4 \mathrm{pg} / \mathrm{ml}$ Vs. $1329.3 \pm 391.1$ $\mathrm{pg} / \mathrm{ml}, P=0.035)$, that were consistently significant even after adjustment for weight, height and serum FSH $(P=0.039, P=0.030, P=0.019)$. Mean serum total ALP level $(P=0.014)$ was significantly higher in the Pro12Ala genotype group compared with the Pro12Pro genotype group $(68.1 \pm 19.2 \mathrm{U} / \mathrm{l}$ Vs. $58.7 \pm 17.3 \mathrm{U} / \mathrm{l}, P=0.014$ ), that were consistently significant even after adjustment for weight, height and serum FSH $(P=0.020, P=0.009, P=$ $0.044)$. Mean values of serum calcium, urine deoxypyridinoline, the ratio of urine calcium and creatinine, BMD, and the ratio of BMD and height between two genotype groups were not significantly different (Table 2). In C161T polymorphism of exon 6 of PPAR- $\gamma$ gene, mean serum OPG level was significantly lower in $\mathrm{T}$ allele carriers compared with non-carriers $(1213.6 \pm 358.4 \mathrm{pg} / \mathrm{ml}$ Vs. 1361.0 $\pm 398.6 \mathrm{pg} / \mathrm{ml}, P=0.003$ ), which was reported previously (Rhee et al., 2005). In multiple regression analysis with serum OPG as the dependent variable and age, weight, ALP, femoral neck BMD and
Pro12Ala polymorphism included in the model as the independent variables, only Pro12Ala polymorphism was the significant determinant of serum OPG level $\left(R^{2}=0.019\right.$, beta $\left.=-0.136, P=0.035\right)$ (data not shown).

The haplotype analysis performed among 4 groups divided according to the presence of minor alleles (Pro12Pro/CC, Pro12Pro/T, Pro12Ala/CC and Pro12Ala/T) showed that subjects having any minor allele showed significantly lower serum OPG levels than subjects with no minor allele (Table 3 ). Subjects carrying Ala and T allele (Pro12Ala/T) showed the lowest serum OPG levels among the hapotype groups. These results were consistently significant even after adjustment for age, weight, height and FSH (Table 3$)(P=0.010)$. Mean total ALP levels showed significant differences among the haplotype groups, although this significance was lost after adjustment for confounding variables (Table 3). Other variables showed no significant difference among the haplotype groups (Table 3 ).

After dividing the subjects into postmenopausal and premenopausal groups, the mean serum OPG levels were compared according to different genotype groups of Pro12Ala polymorphism in PPAR- $\gamma$ gene. In the postmenopausal women, the mean serum OPG level was significantly lower in Pro12Ala genotype group compared with Pro12Pro genotype group $(1,181.2 \pm 359.4 \mathrm{pg} / \mathrm{ml}$ Vs. $1,399.4$ $\pm 373.5 \mathrm{pg} / \mathrm{ml}, P=0.036)$. There were no differences in bone turnover markers and BMDs according to the different genotypes (data not shown). In the premenopausal women, the mean serum OPG 
Table 3. Haplotype analysis between two polymorphisms of PPAR- $\gamma$ gene, Pro12Ala and C161T according to the minor allele status.

\begin{tabular}{|c|c|c|c|c|c|}
\hline Variables & $\begin{array}{l}\text { Pro12Pro/CC } \\
\quad(n=150)\end{array}$ & $\begin{array}{l}\text { Pro12Pro/T* carrier } \\
\qquad(n=65)\end{array}$ & $\begin{array}{l}\text { Pro12Ala/CC } \\
(n=7)\end{array}$ & $\begin{array}{c}\text { Pro12Ala/T* carrier } \\
(n=17)\end{array}$ & $P$ values \\
\hline Age (year) & $51.6 \pm 6.6$ & $50.6 \pm 6.9$ & $54.0 \pm 3.9$ & $51.4 \pm 8.4$ & 0.557 \\
\hline Weight (kg) & $58.5 \pm 8.0$ & $57.8 \pm 7.3$ & $59.4 \pm 7.0$ & $63.7 \pm 8.6$ & 0.051 \\
\hline Height (cm) & $156.0 \pm 5.2$ & $156.3 \pm 4.9$ & $157.7 \pm 5.2$ & $158.5 \pm 4.6$ & 0.216 \\
\hline Serum osteoprotegerin $(\mathrm{pg} / \mathrm{ml})$ & $1364.7 \pm 408.2$ & $1247.5 \pm 337.4^{\dagger}$ & $1344.4 \pm 359.2$ & $1071.2 \pm 381.2^{\dagger}$ & $0.012^{* *}$ \\
\hline Serum calcium $(\mathrm{mg} / \mathrm{dl})$ & $9.0 \pm 0.3$ & $9.0 \pm 0.4$ & $9.2 \pm 0.3$ & $9.0 \pm 0.3$ & 0.271 \\
\hline Serum total ALP $(\mathrm{U} / \mathrm{l})$ & $59.2 \pm 18.1$ & $57.8 \pm 15.2$ & $75.1 \pm 15.2$ & $65.2 \pm 20.3$ & $0.047^{\ddagger}$ \\
\hline Urine DPD (nMol/mMol Cr) & $6.9 \pm 2.0$ & $7.3 \pm 1.8$ & $6.7 \pm 2.2$ & $7.9 \pm 3.0$ & 0.203 \\
\hline 24-h urine $\mathrm{Ca} / \mathrm{Cr}$ & $0.23 \pm 0.1$ & $0.21 \pm 0.1$ & $0.16 \pm 0.1$ & $0.22 \pm 0.1$ & 0.429 \\
\hline Lumbar spine BMD $\left(\mathrm{g} / \mathrm{cm}^{2}\right)$ & $0.96 \pm 0.2$ & $0.95 \pm 0.2$ & $0.95 \pm 0.1$ & $0.96 \pm 0.1$ & 0.995 \\
\hline Femoral neck BMD $\left(\mathrm{g} / \mathrm{cm}^{2}\right)$ & $0.80 \pm 0.1$ & $0.80 \pm 0.1$ & $0.80 \pm 0.1$ & $0.79 \pm 0.1$ & 0.997 \\
\hline
\end{tabular}

${ }^{*} T$ denotes subjects carrying T allele, that is, CT and TT genotypes. Comparisons were performed using ANOVA.

Abbreviations: ALP, alkaline phosphatase; $\mathrm{DPD}$, deoxypyridinoline; $\mathrm{Ca} / \mathrm{Cr}$, calcium to creatinine ratio; $\mathrm{BMD}$, bone mineral density. ${ }^{* *}$ Adjustments were performed using ANCOVA; age $(P=0.014)$, age, weight $(P=0.015)$, age, weight and height $(P=0.012)$ and age, weight, height and FSH $(P=0.010) .{ }^{\dagger}$ In post-hoc analyses, these groups showed significant differences with Pro12Pro/CC genotype group. ${ }^{\ddagger}$ Adjustments were performed using ANCOVA; age $(P$ $=0.076)$, age, weight $(P=0.098)$, age, weight and height $(P=0.107)$ and age, weight, height and FSH $(P=0.211)$.

levels $(1,100.3 \pm 450.5 \mathrm{pg} / \mathrm{ml}$ Vs. $1,269.5 \pm 397.4$ $\mathrm{pg} / \mathrm{ml}, \quad P=0.225)$, bone turnover markers, and BMDs according to the different genotypes were not significantly different (data not shown).

\section{Discussion}

In this study, allelic frequencies were 0.950 for Pro allele and 0.050 for Ala allele and there were no Ala12Ala genotype observed in this Korean population. Mean serum OPG level was significantly lower and serum total ALP was significantly higher in the Pro12Ala genotype group compared with the Pro12Pro genotype group, which were consistently significant even after adjustment for other confounding factors. In multiple regression analysis with serum OPG as the dependent variable, only Pro12Ala polymorphism was the significant determinant of serum OPG level among the variables after adjustment for confounding factors. In the haplotype analysis performed in association with another PPAR- $\gamma$ gene polymorphism, C161T in exon 6 , in which the association with bone and OPG were observed in the previous studies, subjects with minor alleles showed significantly lower serum OPG levels than those with no minor allele, suggesting the negative effects of PPAR- $\gamma$ gene on serum OPG levels.

PPAR- $\gamma$ is primarily found in white adipose tissue and mainly known to be involved in the terminal differentiation of preadipocyte into mature adipocyte (Desvergne and Wahli, 1999). The hypothesis that PPAR- $\gamma$ might be involved in bone metabolism has derived from the fact that osteoblasts and adipocytes share a common mesenchymal precursor cell (Desvergne and Wahli, 1999; Thomas et al., 1999). Although the precise conclusion has not been determined yet, there are several studies to date regarding the role of PPAR- $\gamma$ on osteoblast differentiation and activity. Nuttall (1998) and Lecka-Czernik et al. $(1999,2002)$ have revealed that the activation of PPAR- $\gamma$ would promote adipose cell differentiation in various precursor cells, and recent studies by various study groups reported the negative effect of PPAR- $\gamma$ agonist treatment on the differentiation of precursor cell lines into osteoblast and the osteoblast activity in the cell culture studies, although some studies showed different results depending on the concentrations of the treated regimen (Jackson and Demer, 2000; Rzonca et al., 2004; Ali et al., 2005; Lazarenko et al., 2006). Regarding the role of PPAR- $\gamma$ activation on osteoblastogenesis, recent work by Akune et al. (2004) drew attention. Using heterozygous PPAR- $\gamma$ deficient mice (PPAR- $\gamma+/-$ ) instead of homozygous mice which were embrionically lethal due to placental dysfunction, which showed a $50 \%$ reduction in PPAR- $\gamma$ expression, they showed that PPAR- $\gamma$ insufficiency increased bone mass by stimulating osteoblastogenesis from bone marrow progenitor cells, which supports the negative role of PPAR- $\gamma$ activation on bone formation. These results from the cell culture and animal studies of the role of PPAR- $\gamma$ activation on osteoblastogenesis have to be confirmed in well-controlled randomized human studies in the future to draw a precise conclusion.

In contrast to the numerous studies performed regarding the role of PPAR- $\gamma$ activation on osteo- 
blastogenesis, there are few studies on its role on osteoclastogenesis. Mbalaviele et al. (2000) showed that the activation of PPAR- $\gamma$ pathway by an endogenous PPAR- $\gamma$ ligand, blocked the effects of OPG ligand and thus, inhibited the formation and activity of osteoclasts in human mesenchymal stem cells through the inhibition of receptor-activated $N F-\kappa B$ ligand (RANKL) blocking the NF- $\kappa B$ pathway. Okazaki et al. (1999) similarly reported that the thiazolidindione treatment decreased the number of osteoclast-like cells induced by $1,25-$ $(\mathrm{OH}) 2 \mathrm{D} 3$ or $\mathrm{PTH}$, suggesting the inhibitory role of PPAR- $\gamma$ activation on bone resorption. Very recent work by Chan et al. (2007) demonstrated that PPAR- $\gamma$ agonist added to human peripheral blood mononuclear cells culture resulted in significant dose-dependent inhibition of multinucleated osteoclast formation. Although the precise mechanisms regarding the association of PPAR- $\gamma$ and osteoclastogenesis are not clarified, the antagonistic effects of PPAR- $\gamma$ on the transcription factor NF- $\kappa B$, which is the fundamental pathway for RANKL signaling and essential for osteoclast development, survival and function, and the subsequent association of osteoprotegerin, a critical inhibitory factor in osteoclastogenesis, are suggested (Mbalaviele et al., 2000).

OPG is a circulating receptor without a transmembrane domain and it inhibits osteoclast differentiation by acting as a decoy receptor to RANK that is expressed on the osteoclast precursor surface, and it interferes with RANK's interaction with RANKL (Simonet et al., 1997; Yasuda et al., 1998; Woo et al., 2002). Considering that NF- $\kappa$ B pathway is involved in the inhibitory mechanism of cytokine in adipocyte differentiation through downregulation of PPAR- $\gamma$ (Chae and Kwak, 2003) and the previously mentioned mechanism of PPAR- $\gamma$ agonist inhibiting osteoclast differentiation through the inhibition of NF- $\mathrm{B}$ transcription for inhibiting RANKL signaling, we could assume that the inhibition of osteoclastogenesis by OPG might have direct association with PPAR- $\gamma$ activation. In this study, mean serum OPG level was significantly lower and serum total ALP was significantly higher in the Pro12Ala genotype group compared with the Pro12Pro genotype group, even after adjustment for other confounding factors, and Pro12Ala was the significant determinant of serum OPG levels in the multiple regression analysis. In the haplotype analysis performed in association with C161T polymorphism, subjects with minor alleles showed significantly lower serum OPG levels than those with no minor alleles, suggesting negative effects of these polymorphisms on serum OPG levels. If the reduced serum OPG level just reflects the osteo- clastogenic status, then the result might be interpreted as that the presence of the polymorphisms decreased the osteoclastogenesis and the the serum OPG level was reduced, suggesting the polymoprhisms as the significant effector for the bone resorption. However, this interpretation is just a precision, since BMD values did not show any differences according to the genotypes of either polymorphisms and the transcriptional factors or the signaling molecules regarding the osteoclastogenesis were not analyzed in this study; therefore the results have to be seen as merely a phenomenon.

In a previous study, Ala allele carriers showed a significantly higher BMI than non carriers in a meta-analysis that assessed more than 30 independent Pro12Ala studies (Masud and Ye, 2003). Similar to that study, subjects with Pro12Ala had higher weight than subjects with Pro12Pro in this study. Although the BMD values did not show significant differences between the genotypes, if OPG might reflect the bone metabolism, the decreased body weight in Pro12Pro genotype group might have negative effects on bone, and the OPG might have increased as a compensatory mechanism for the protection against bone resorption. However, this is just an assumption and further studies are needed to clarify the relationship between Pro12Ala polymorphism and bone.

In this study, subjects with Pro12Ala genotype were significantly taller than those without Ala allele. As for the relationship between the components of weight, that is, lean vs. fat mass, and bone density, Reid et al. (1992) previously reported that in men, the relationship of lean or fat masses were unrelated to bone density once the effects of skeletal size were removed, which was expressed by height, and for premenopausal women in the same study, the effect of lean mass on BMD was no longer observed when BMD was expressed as a ratio to height, reflecting the function of body size. In a previous study by Meirhaegue et al. (2003) carriers of $-681 \mathrm{G}$ allele in the PPAR- $\gamma 3$ polymorphism in exon A2 showed higher height, implicating the possible involvement of PPAR- $\gamma$ in the growth of skeleton. The authors suggested the possible association between PPAR- $\gamma$ and growth hormone as the mechanism. Another study done in young schoolchildren supports the notion that PPAR- $\gamma$ might affect the skeletal growth (Cecil et al., 2005). In that study, although no single variant of PPAR- $\gamma$ gene was associated with height, weight or BMI, when the variants were modeled together, they observed an apposing interaction between the $-681 \mathrm{G}$ of PPAR- $\gamma$ and Ala12 variants in height and weight in prepubertal children aged be- 
tween 4 and $10 \mathrm{yrs}$, that is, reduced growth in Ala allele bearers in this study group. This previous study was in opposition to our result in that Ala carriers showed the genotype of decreased height. However, in that study, primary analyses done between the body size and the individual PPAR- $\gamma$ polymorphisms failed to show significant association, which means that the association might have been affected by the modeling of the two polymorphisms together. From these aspects, we compared the mean values of BMD after expressing the BMD with a ratio to height, in the efforts to abolish the effect of body size, and the results did not show any difference. Furthermore, the significant differences in OPG levels between Pro12Ala genotype groups seen in this study might be more meaningful, as the results were adjusted with weight and height, suggesting that the differences might not be affected by the effects of body mass, but might be the independent effector in the bone metabolism. Whether Pro12Ala polymorphism might affect bone mass through affecting the lean mass or the fat mass, might be an interesting issue that could be investigated in the future.

Another interesting point to discuss is that, when the subjects were divided into two groups according to the menopausal status, the lower level of serum OPG in Pro12Ala genotype group was significant only in postmenopausal women, which was the similar to the result of our previous paper that analyzed the relationship between serum OPG level and C161T polymorphism in PPAR $\gamma$ gene (Rhee et al., 2005). In that study, T allele carriers, which is the minor allele of the polymorphism, also showed significantly lower serum OPG levels compared to the dominant genotype group, and the significance was consistent also, only in postmenopausal group. As the authors described in the previous paper, the effect of OPG in the osteoclastogenesis might have been more strengthened in postmenopausal status, as the protective effect of estrogen to osteoclastogenesis could have overwhelmed the influence of PPAR gene on bone in premenopausal status. However, since the precise mechanism linking PPAR $\gamma$ and OPG in bony environment is not clearly established, these presumptions could be a bit too speculative, although the similar results observed in different polymorphisms in the same gene could at least support the presumption.

In conclusion, Pro12Ala polymorphism did not show any association with BMD values in this Asian subjects, although serum OPG levels were significantly lower in Ala carriers, which partly suggests the protective role of Ala allele in bone re- sorption and osteoclastogenesis. This significance was strengthened in haplotype analysis with another PPAR- $\gamma$ polymorphism, C161T in exon 6 , suggesting the association of PPAR- $\gamma$ with OPG in vivo. Although the results of this study have to be interpreted with caution, this was the first study to analyze the association Pro12Ala polymorphism with serum OPG levels and BMD in human. And this study result might suggest at least a small clue to the recent debates on the relationship of thiazolidinediones on bone metabolism. More research is needed on this issue in the future, and extended studies in different ethnic groups and different populations will clarify whether this is the direct effect of PPAR- $\gamma$ on bone or the indirect effect through its effects on fat or insulin resistance.

\section{Acknowledgments}

These results were presented at the ECTS 34th European Symposium on Calcified Tissues, Copenhagen, Denmark, May 5-9, 2007. This work was supported by the Korea Research Foundation Grant funded by the Korean Government (KRF-2005-041-E00251).

\section{References}

Akune T, Ohba S, Kamekura S, Yamaguchi M, Chung UI, Kubota N, Terauchi Y, Harada Y, Azuma Y, Nakamura K, Kadowaki T, Kawaguchi H. PPARgamma insufficiency enhances osteogenesis through osteoblast formation from bone marrow progenitors. J Clin Invest 2004;113:846-55

Ali AA, Weinstein RS, Stewart SA, Parfitt AM, Manolagas SC, Jilka RL. Rosiglitazone causes bone loss in mice by suppressing osteoblast differentiation and bone formation. Endocrinology 2005;146:1226-35

Altshuler D, Hirschhorn JN, Klannemark M, Lindgren CM, Vohl MC, Nemesh J, Lane CR, Schaffner SF, Bolk S, Brewer C, Tuomi T, Gaudet D, Hudson TJ, Daly M, Groop L, Lander ES. The common PPAR $\gamma$ Pro12Ala polymorphism is associated with decreased risk of type 2 diabetes. Nat Genet 2000;26:76-80

Barrett JC, Fry B, Maller J, Daly MJ. Haploview: analysis and visualization of LD and haplotype maps. Bioinformatics 2005;21:263-5

Cecil JE, Fischer B, Doney AS, Hetherington M, Watt P, Wrieden W, Bolton-Smith C, Palmer CN. The Pro12Ala and C-681G variants of the PPARG locus are associated with opposing growth phenotypes in young schoolchildren. Diabetologia 2005;48:1496-502

Chae GN, Kwak SJ. NF-kappaB is involved in the TNF-alpha induced inhibition of the differentiation of 3T3-L1 cells by reducing PPARgamma expression. Exp Mol Med 2003;35: 431-7

Chan BY, Gartland A, Wilson PJM, Buckley KA, Dillon JP, 
Fraser WD, Gallagher JA. PPAR agonists modulate human osteoclast formation and activity in vitro. Bone 2007;40:14959

Clement K, Hercberg S, Passinge B, Galan P, Varroud-Vial M, Shuldiner AR, Beamer BA, Charpentier G, Guy-Grand B, Froguel P, Vaisse C. The Pro115GIn and Pro12Ala PPAR $\gamma$ gene mutations in obesity and type 2 diabetes. Int $\mathrm{J}$ Obes Relat Metab Disord 2000;24:391-3

Desvergne B, Wahli W. Peroxisome proliferators-activated receptors: nuclear control of metabolism. Endocr Rev 1999; 20:649-88

Fajas L, Auboeuf D, Raspe E, Schoonjans K, Lefebvre AM, Saladin R, Najib J, Laville M, Fruchart JC, Deeb S, Vidal-Puig A, Flier J, Briggs MR, Staels B, Vidal H, Auwerx J. The organization, promoter analysis, and expression of the human PPAR $\gamma$ gene. J Biol Chem 1997;272:18779-89

Hara K, Okada T, Tobe K, Yasuda K, Mori Y, Kadowaki H, Hagura R, Akanuma Y, Kimura S, Ito C, Kadowaki T. The Pro12Ala polymorphism in PPAR gamma2 may confer resistance to type 2 diabetes. Biochem Biophys Res Commun 2000;271:212-6

Jackson SM, Demer LL. Peroxisome proliferator-activated receptor activators modulate the osteoblastic maturation of MC3T3-E1 preosteoblasts. FEBS Letters 2000;471:119-24

Kahn SE, Haffner SM, Heise MA, Herman WH, Holman RR, Jones NP, Kravitz BG, Lachin JM, O'Neill MC, Zinman B, Viberti G; ADOPT Study Group. Glycemic durability of rosiglitazone, metformin, or glyburide monotherapy. N Engl J Med 2006;355:2427-43

Kersten S, Desvergne B, Wahli W. Roles of PPARs in health and disease. Nature 2000;405:421-4

Lazarenko OP, Rzonca SO, Suva LJ, Lecka-Czernik B. Netoglitazone is a PPAR-gamma ligand with selective effects on bone and fat. Bone 2006;38:74-84

Lecka-Czernik B, Gubrij I, Moerman EJ, Kajkenova O, Lipschitz DA, Manolagas SC, Jilka RL. Inhibition of Osf2/ Cbfa1 expression and terminal osteoblast differentiation by PPARgamma2. J Cell Biochem 1999;74:357-71

Lecka-Czernik B, Moerman EJ, Grant DF, Lehmann JM, Manolagas SC, Jilka RL. Divergent effects of selective peroxisome proliferator-activated receptor-gamma 2 ligands on adipocyte versus osteoblast differentiation. Endocrinology 2002;143:2376-84

Mancini FP, Vaccaro O, Sabatino L, Tufano A, Rivellese AA, Riccardi G, Colantuoni V. Pro12Ala substitution in the peroxisome proliferator-activated receptor- $\gamma 2$ is not associated with type 2 diabetes. Diabetes 1999;48:1466-8

Masud S, Ye S. Effect of the peroxisome proliferator activated receptor-gene Pro12Ala variant on body mass index: a meta-analysis. J Med Genet 2003;40:773-80

Mbalaviele G, Abu-Amer Y, Meng A, Jaiswal R, Beck S, Pittenger MF, Thiede MA, Marshak DR. Activation of peroxisome proliferator-activated receptor-gamma pathway inhibits osteoclast differentiation. J Biol Chem 2000;275:1438893

Meirhaeghe A, Fajas L, Helbecque N, Cottel D, Auwerx J,
Deeb SS, Amouyel P. Impact of the Peroxisome Proliferator Activated Receptor gamma2 Pro12Ala polymorphism on adiposity, lipids and non-insulin-dependent diabetes mellitus. Int J Obes Relat Metab Disord 2000;24:195-9

Meirhaeghe A, Fajas L, Gouilleux F, Cottel D, Helbecque N, Auwerx J, Amouyel P. A functional polymorphism in a STAT5B site of the human PPAR gamma 3 gene promoter affects height and lipid metabolism in a French population. Arterioscler Thromb Vasc Biol 2003;23:289-94

Nuttall ME, Patton AJ, Olivera DL, Nadeau DP, Gowen M. Human trabecular bone cells are able to express both osteoblastic and adipocytic phenotype: implications for osteopenic disorders. J Bone Miner Res 1998;13:371-82

Ogawa S, Urano T, Hosoi T, Miyao M, Hoshino S, Fujita M, Shiraki M, Orimo H, Ouchi Y, Inoue S. Association of Bone mineral density with a polymorphism of the peroxisome proliferator-activated receptor g gene: PPAR $\gamma$ expression in osteoblasts. Biochem Biophys Res Commun 1999;260:1226

Okazaki R, Toriumi M, Fukumoto S, Miyamoto M, Fujita T, Tanaka K, Takeuchi Y. Thiazolidinediones inhibit osteoclast-like cell formation and bone resorption in vitro. Endocrinology 1999;140:5060-5

Reid IR, Plank LD, Evans MC. Fat mass is an important determinant of whole body bone density in premenopausal women but not in men. J Clin Endocrinol Metab 1992;75: 779-82

Rhee EJ, Oh KW, Lee WY, Kim SY, Oh ES, Baek KH, Kang MI, Kim SW . The effects of C161 $\rightarrow$ T polymorphisms in exon 6 of peroxisome proliferator-activated receptor-gamma gene on bone mineral metabolism and serum osteoprotegerin levels in healthy middle-aged women. Am J Obstet Gynecol 2005;192:1087-93

Rhee EJ, Oh KW, Lee WY, Kim SY, Oh ES, Baek KH, Kang $\mathrm{MI}$, Kim SW. Effects of two common polymorphisms of peroxisome proliferator-activated receptor-gamma gene on metabolic syndrome. Arch Med Res 2006;37:86-94

Ringel J, Engeli S, Distler A, Sharma AM. Pro12Ala missense mutation of the peroxisome proliferator activated receptor $g$ and diabetes mellitus. Biochem Biophys Res Commun 1999;254:450-3

Rosen ED, Spiegelman BM. PPARgamma: a nuclear regulator of metabolism, differentiation, and cell growth. J Biol Chem 2001;276:37731-4

Rzonca SO, Suva LJ, Gaddy D, Montague DC, LeckaCzernik B. Bone is a target for the antidiabetic compound rosiglitazone. Endocrinology 2004;145:401-6

Schwartz AV, Sellmeyer DE, Vittinghoff E, Palermo L, Lecka-Czernik B, Feingold KR, Strotmeyer ES, Resnick HE, Carbone L, Beamer BA, Park SW, Lane NE, Harris TB, Cummings SR. Thiazolidinedione use and bone loss in older diabetic adults. J Clin Endocrinol Metab 2006;91:3349-54

Simonet WS, Lacey DL, Dunstan CR, Kelley M, Chang MS, Luthy $R$, Nguyen $H Q$, Wooden $S$, Bennett L, Boone $T$, Shimamoto G, DeRose M, Elliott R, Colombero A, Tan HL, Trail G, Sullivan J, Davy E, Bucay N, Renshaw-Gegg L, Hughes TM, Hill D, Pattison W, Campbell P, Sander S, Van 
G, Tarpley J, Derby P, Lee R, Boyle WJ. Osteoprotegerin: a novel secreted protein involved in the regulation of bone density. Cell 1997;89:309-19

Sorocéanu MA, Miao D, Bai XY, Su H, Goltzman D, Karaplis AC. Rosiglitazone impacts negatively on bone by promoting osteoblast/osteocyte apoptosis. J Endocrinol 2004;183: 203-16

Thomas T, Gori F, Khosla S, Jensen MD, Burguera B, Riggs $B L$. Leptin acts on human marrow stromal cells to enhance differentiation to osteoblasts and to inhibit differentiation to adipocytes. Endocrinology 1999;140:1630-8
Woo KM, Choi Y, Ko SH, Ko JS, Oh KO, Kim KK. Osteoprotegerin is present on the membrane of osteoclasts isolated from mouse long bones. Exp Mol Med 2002;34:347-52

Yasuda H, Shima N, Nakagawa N, Mochizucki SI, Yano K, Fujise N, Sato Y, Goto M, Yamaguchi K, Kuriyama M, Kanno T, Murakami A, Tsuda E, Morinaga T, Higashio K. Identity of osteoclastogenesis inhibitory factor (OCIF) and osteoprotegerin (OPG): a mechanism by which OPG/OCIF inhibits osteoclastogenesis in vitro. Endocrinology 1998;39:132937 